\title{
Analisis Kewirausahaan Ibu-Ibu PKK Di Komplek Perumahan Kota Pekanbaru
}

\author{
ASNAHWATI \\ Dosen Tetap Sekolah Tinggi Ilmu Ekonomi Riau \\ Jln. HR. Subrantas 57 Panam Pekanbaru 28293 Telp. (0761) 63237 \\ E-mail : asnahwati357@yahoo.com
}

\begin{abstract}
Entrepreneurship is not always identical with the behavior and character of entrepreneurs because it is also owned by non-entrepreneurs, such as private and government employees. Even in this case it could be a housewife. Operationally, housewife is a manager who manages household finances and needs to give his or her creative arts in optimizing in increasing household income. Through survey conducted in the field and analyzed by descriptive analysis. The results showed that the entrepreneurial spirit of housewives in the PKK group was in good category, especially in terms of following social activities and communication skills, but still low in terms of challenges of housewife facing the economic condition of the family.
\end{abstract}

Keywords: Entrepreneurial housewives

Kondisi perekonomian yang belum stabil seperti sekarang ini membuat ibu rumah tangga menanggung beban dalam pengeluaran rumah tangganya. Beban dalam rumah tangga khususnya rumah tangga miskin menjadi pekerjaan rumah yang berat dan perlu mendapatkan solusinya. Menurut Badan Pusat Statistik (BPS, 2015) mendefiniskan kemiskinan dengan menggunakan pendekatan konsumsi (satu dimensi). Dengan pendekatan ini, ditentukan ukuran konsumsi standar kehidupan yang "layak" dengan melihat kebutuhan dasar (basic need approach) yang menghasilkan Garis Kemiskinan (makanan dan bukan makanan).

Garis Kemiskinan merupakan gabungan dari Garis Kemiskinan Makanan (GKM) dan Garis Kemiskinan non Makanan (GKBM). GKM adalah nilai rupiah pengeluaran untuk kebutuhan minimum makanan yang disetarakan dengan 2100 kalori per kapita per hari. Paket komoditi kebutuhan dasar makanan ini diwakili oleh 52 jenis komoditi (padipadian, umbi-umbian, ikan, daging, telur, susu, sayuran, kacang-kacangan, buahbuahan, minyak lemak, dll sedangkan GKBM adalah nilai rupiah pengeluaran untuk memenuhi kebutuhan dasar minimum non makanan yaitu papan, sandang, sekolah, trasportasi serta kebutuhan individu dan rumah tangga dasar lainnya. Paket komoditi kebutuhan dasar non makanan diwakili oleh 51 jenis komoditi (kelompok pengeluaran) di perkotaan dan 47 jenis komoditi (kelompok pengeluaran di pedesaan).

Salah satu pilihan yang bisa dilakukan kaum ibu dalam meningkatkan pendapatan keluarganya secara manajerial yakni melalui jiwa kewirausahaan ibu rumah tangga dalam melihat peluang usaha hingga mengaplikasikan dalam kondisi nyata.

Kata entrepreneurship yang dahulunya sering diterjemahkan dengan kata kewiraswastaan akhir-akhir ini diterjemahkan dengan kata kewirausahaan. Entrepreneur berasal dari bahasa Perancis yaitu entreprendre yang artinya memulai atau melaksanakan. Wiraswasta/wirausaha berasal dari kata: Wira: utama, gagah berani, luhur; swa: sendiri; sta: berdiri; usaha: kegiatan produktif Dari asal kata tersebut, wiraswasta pada mulanya ditujukan pada orang-orang yang dapat berdiri sendiri. Di Indonesia kata wiraswasta sering diartikan sebagai orang-orang yang tidak bekerja 
pada sektor pemerintah yaitu; para pedagang, pengusaha dan orang-orang yang bekerja di perusahaan swasta, sedangkan wirausahawan adalah orang-orang yang mempunyai usaha sendiri

Jong and Wennekers (2008) menyatakan bahwa kewirausahaan dapat didefinisikan sebagai pengambilan risiko untuk menjalankan usaha sendiri dengan memanfaatkan peluang-peluang untuk menciptakan usaha baru atau dengan pendekatan yang inovatif sehingga usaha yang dikelola berkembang menjadi besar dan mandiri dalam menghadapi tantangantantangan persaingan. Kata kunci dari kewirausahaan adalah: pengambilan resiko, menjalankan usaha sendiri, memanfaatkan peluang-peluang, menciptakan usaha baru, pendekatan yang inovatif dan mandiri (misal;tidak bergantung pada bantuan pemerintah)

Gambaran ideal seorang wirausahawan menurut Alma (2010: 21) adalah orang yang dalam keadaan bagaimanapun daruratnya, tetap mampu berdiri atas kemampuan sendiri untuk menolong dirinya keluar dari kesulitan yang dihadapi, termasuk mengatasi kemiskinan tanpa bantuan siapapun. Bahkan dalam keadaan yang biasa (tidak darurat), mampu menjadikan dirinya maju, kaya, berhasil lahir dan bathin. mampu mandiri, menolong dirinya sendiri dalam menghadapi kesulitan hidup.

Berdasarkan hasil penelitian Apriliyanti, dapat disimpulkan:

1. Potensi kepribadian wirausaha berpengaruh positif dan signifikan terhadap minat berwirausah siswa SMK Rumpun Pertanian di Daerah Istimewa Yogyakarta.

2. Pengetahuan kewirausahaan berpengaruh positif dan signifikan terhadap minat berwirausaha siswa SMK Rumpun Pertanian di Daerah Istimewa Yogyakarta.

3. Lingkungan keluarga berpengaruh positif dan signifikan terhadap minat berwirausaha siswa SMK Rumpun
Pertanian di Daerah Istimewa Yogyakarta.

4. Potensi kepribadian wirausaha, pengetahuan kewirausahaan, dan lingkungan keluarga secara bersamasama berpengaruh positif dan signifikan terhadap minat berwirausaha siswa SMK Rumpun Pertanian di Daerah Istimewa Yogyakarta.

Berdasarkan teori diatas maka diharapkan ibu-ibu PKK memiliki potensi kepribadian wirausaha agar mampu membuka peluang kerja bagi dirinya sendiri dan orang lain sehingga bisa membantu meningkatkan pendapatan keluarga yang ahkirnya otomatis akan meningkatkan kesejahteraan keluarga.

Namun kenyataan yang ada di masyarakat, kewirausahaan yang dilakukan oleh kaum perempuan atau ibuibu rumah tangga belumlah optimal. Hal ini terbukti dengan masih banyaknya ditemukan keluarga yang belum sejahtera dipandang dari segi ekonomi. Masih banyak ibu-ibu yang mengeluh dengan harga sembako di pasar. Maka dari itu, pada penelitian ini akan difokuskan pada analisis jiwa kewirausahaan ibu-ibu PKK. Bagaimana keadaan jiwa kewirausahaan ibu-ibu PKK, sudah baik atau belum.

Berikut ini Menurut Salim Siagian dan Asfahani (1996) dalam PO Abas Sunaryo, Sudaryono dan Asep Saefullah (2011:45)), ada 8 syarat pokok sebagai wirausaha yang handal yaitu:

1. Memiliki rasa percaya diri dan sikap mandiri yang tinggi dalam berusaha mencari penghasilan dan keuntungan melalui perusahaan.

2. Mau dan mampu mencari dan menangkap peluang usaha yang menguntungkan serta melakukan apa saja yang perlu untuk memanfaatkannya.

3. Mau dan mampu bekerja keras dan tekun dalam menghasilkan barang dan atau jasa serta mencoba cara kerja yang lebih tepat dan efisien. 
4. Mau dan mampu berkomunikasi, tawar menawar dan musyawarah dengan berbagai pihak yang besar pengaruhnya pada kemajuan usaha terutama para pembeli/ pelanggan (memiliki jiwa salesmanship).

5. Menghadapi hidup dan menangani usaha dengan rencana, jujur, hemat dan disiplin.

6. Mencari kegiatan usaha dan perusahaannya serta lugas dan tangguh tetapi cukup luwes dalam melindunginya.

7. Mau dan mampu meningkatkan kapasitas diri sendiri dan kapasitas perusahaan dengan memanfaatkan dan memotivasi orang lain (leadership / manajemenship) serta melakukan perluasan dan pengembangan usaha dengan resiko yang moderat.

8. Berusaha mengenal dan mengendalikan lingkungan serta menggalang kerjasama yang saling menguntungkan dengan berbagai pihak yang berkepentingan terhadap perusahaan.

Variabel

karakteristik

kewirausahaan yang meliputi: faktor mampu mengatasi kegagalasn ( adapted to change), mampu mengatasi perubahan (ability to risk failure) keinginan berkembang (desire of growth), keinginan untuk unggul (take advantage of the oportunity), memiliki pengetahuan baru (ability to search and having knowladge). mempunyai pengaruh signifikan dan positif terhadap kompetensi usaha dan kinerja Usaha Mikro dan Kecil (UMK) di Kota Balikpapan. SeVariabell kompetensi usaha yang meliputi: faktor memiliki pengetahuan usaha (knowledge), memiliki ketrampilan usaha (skill), memiliki kemampuan berusaha (ability) mempunyai pengaruh terhadap kinerja Usaha Mikro dan Kecil (UMK) di Kota Balikpapan.

\section{METODE}

Penelitian ini dilakukan melalui penelitian survey dengan studi pada ibu-ibu rumah tangga dengan menggunakan sampel yang diambil secara simple Ramdom Sampling. Data primer didapatkan dengan membagikan kuisioner kepada 23 orang ibu-ibu rumah tangga yang tinggal di perumahan sederhana dan seterusnya dianalisa secara deskriptif.

\section{HASIL}

Berdasarkan hasil survey di lapangan berkaitan dengan kewirausahaan sebagai wujud kreatifitas dan inovasi dalam rangka meningkatkan pendapatan rumah tangga dapat dilihat pada uraian data berikut ini:

Dari beberapa indikator kewirausahaan yang telah disebutkan sebelumnya, maka dapat dibuat rekapitulasi data sebagai berikut:

Tabel 1: Kewirausahaan dilihat dari seluruh indikator kewirausa haan

\begin{tabular}{|l|l|l|}
\hline No & Pertanyaan & Skor \\
\hline 1 & $\begin{array}{l}\text { Bagaimana rasa percaya diri ibu } \\
\text { dalam bergabung dalam kelompok } \\
\text { ibu-ibu PKK ini? }\end{array}$ & 4,30 \\
\hline 2 & $\begin{array}{l}\text { Bagaimana manfaat yang ibu } \\
\text { rasakan setelah mengikuti acara } \\
\text { ini? }\end{array}$ & 4,26 \\
\hline 3 & $\begin{array}{l}\text { Bagaiaman keinginan ibu dalam } \\
\text { mempelajari kegiatan ini? }\end{array}$ & 4,13 \\
\hline 4 & $\begin{array}{l}\text { Bagaimana komunikasi ibu dengan } \\
\text { sesama anggota dalam kelompok } \\
\text { ibu-ibu PKK ini? }\end{array}$ & 4,43 \\
\hline 5 & $\begin{array}{l}\text { Bagaimana tantangan hidup ibu } \\
\text { dalam menghadapi kondisi } \\
\text { ekonomi keluarga saat ini? }\end{array}$ & 3,87 \\
\hline 6 & $\begin{array}{l}\text { Bagaimana ide kreatif yang ibu } \\
\text { peroleh selama mengikuti kegiatan } \\
\text { ini? }\end{array}$ & 4,00 \\
\hline 7 & $\begin{array}{l}\text { Bagaiaman keinginan ibu dalam } \\
\text { menambah pengetahuan melalui } \\
\text { kegiatan sosial ini? }\end{array}$ & 4,13 \\
\hline 8 & $\begin{array}{l}\text { Bagaimana posisi ibu untuk } \\
\text { mengaktualisasikan diri } \\
\text { (menempatkan diri sesuai dengan } \\
\text { kemampuan yang dimiliki) melalui } \\
\text { kegiatan sosial ini? }\end{array}$ \\
\hline & $\begin{array}{l}\text { Rata-rata } \\
\text { Sum }\end{array}$ \\
\hline ber Data Olahan, 2016 \\
\hline
\end{tabular}

Sumber: Data Olahan, 2016

p.ISSN: $2407-800 X$

e.ISSN: $2541-4356$ 
Dari 8 indikator jiwa kewirausahaan yang dimiliki ibu-ibu rumah tangga pada kelompok PKK dapat dilihat bahwa indikator tertinggi yaitu kemampuan berkomunikasi ibu-ibu dengan mengikuti kegiatan sosial bernilai lebih tinggi dibandingkan dengan yang lainnya (skor $=4,43$ ) sedangkan indikator paling rendah adalah tantangan ibu rumah tangga menghadapi kondisi ekonomi keluarga $($ skor $=3,87)$.

\section{PEMBAHASAN}

Dari hasil penelitian di atas dapat dijelaskan bahwa jiwa kewirausahaan yang dimiliki ibu-ibu rumah tangga pada kelompok PKK RT 03 RW 23 Perum Graha Rawa Bangun Kel Tuah Karya Kec Tampan Kota Pekanbaru dalam kondisi baik $(4,15$ pada skala 5).

\section{Kewirausahaan Perempuan Dilihat dari Indikator Percaya Diri}

Rasa percaya diri bermaksud perempuan memiliki rasa percaya diri dan sikap mandiri yang tinggi dalam berusaha mencari penghasilan dan keuntungan melalui kelompok arisan PKK. Hasil penelitian yang dilakukan dapat dilihat pada grafik dibawah ini.

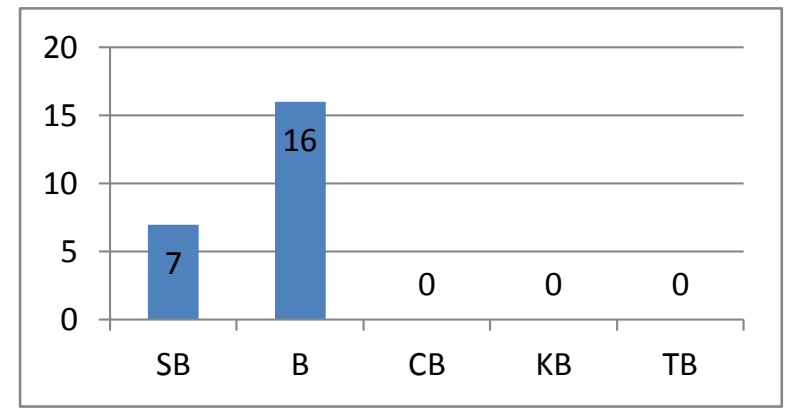

Gambar 1:

\section{Rasa Percaya Diri Ibu Rumah Tangga}

Dari gambar tersebut menunjukkan bahwa responden sebanyak 16 orang dari 23 orang memberikan jawaban baik yang berarti bahwa sebagai ibu rumah tangga yang bergabung dalam kelompok arisan PKK memiliki rasa percaya diri yang baik. Hal ini ditunjukkan dengan aktifnya ibu rumah tangga dalam mengikuti acara yang diselenggarakan oleh kelompok PKK seperti selalu hadir pada setiap kegiatan arisan dan juga selalu mengikuti berbagai kegiatan keterampilan dan juga motivasi baik yang berasal dari dalam kelompok itu sendiri maupun yang berasal dari luar kelompok, seperti dari ustad dan ustazah penceramah dan juga dari kelompok perguruan tinggi yang melaksanakan pengabdian.

Hasil penelitian ini apabila dibandingkan dengan hasil penelitian terdahulu sebagaimana disampaikan oleh SRI MARWANTI1, ISMI DWI ASTUTI, 1 Peneliti P3G LPPM dan Staf Pengajar Program Studi Agribisnis, Fakultas Pertanian, Universitas Sebelas Maret Surakarta 2 Peneliti P3G LPPM dan Staf Pengajar Program Studi Administrasi Negara, Fakultas Ilmu Sosial dan Politik, Universitas Sebelas Maret Surakarta (2012) yang mengatakan bahwa berdasarkan hasil analisis mengenai potensi, peluang, hambatan dan kebijakan serta program Pemerintah Kabupaten Karanganyar yang berkaitan dengan pemberdayaan perempuan miskin, maka dapat dirumuskan sebuah model yang disebut pro-poor capacity improvement model (PCIM). Berdasarkan model PCIM ini, pemberdayaan yang perlu dilakukan antara lain: dengan berbagai intervensi yang dilakukan, diharapkan tumbuh kewirausahaan keluarga yang ditandai dengan menguatnya rasa percaya diri, berkembangnya kreativitas, tumbuhnya inovasi, tangguh terhadap berbagai macam situasi yang fluktuatif, dan fleksibel sehingga usaha-usaha yang mereka lakukan mampu meningkatkan sumber pendapatan ekonomi keluarga perempuan miskin dan usahanya berkembang secara berkelanjutan.

\section{Kewirausahaan Perempuan Dilihat dari indikator manfaat}

Manfaat yang dimaksud adalah perempuan mau dan mampu mencari dan menangkap peluang usaha yang menguntungkan serta melakukan apa saja yang perlu untuk memanfaatkannya melalui kelompok arisan PKK. Hasil penelitian yang dilakukan dapat dilihat pada grafik dibawah ini. 


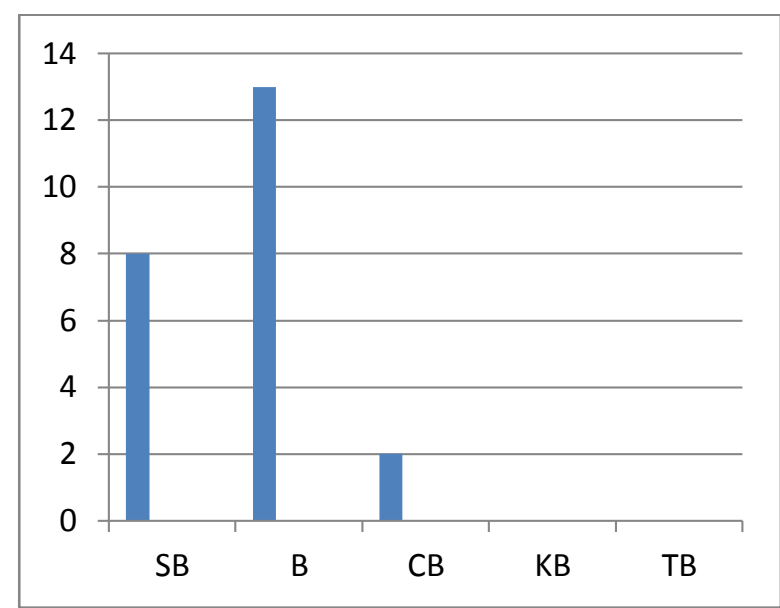

Gambar 2:

Manfaat

Dari gambar di atas menunjukkan bahwa responden sebanyak 13orang dari 23 orang memberikan jawaban baik yang berarti bahwa sebagai ibu rumah tangga yang bergabung dalam kelompok arisan PKK memiliki kemampuan dalam mencari dan menangkap peluang yang baik dalam berusaha mencari penghasilan dan keuntungan melalui kelompok arisan PKK. Hal ini ditunjukkan dengan aktifnya ibu rumah tangga dalam mengikuti acara yang diselenggarakan oleh kelompok PKK seperti selalu hadir pada setiap kegiatan arisan dan juga selalu mengikuti berbagai kegiatan keterampilan dan juga motivasi baik yang berasal dari dalam kelompok itu sendiri maupun yang berasal dari luar kelompok, seperti dari ustad dan ustazah penceramahdan juga dari kelompok perguruan tinggi yang melaksanakan pengabdian.

\section{Kewirausahaan Perempuan Dilihat dari indikator Keinginan Mempelajari Kegiatan}

Keinginan mempelajari kegiatan bermaksud perempuan memiliki keinginan yang tinggi dalam bekerja keras dan tekun dalam menghasilkan barang dan atau jasa serta mencoba cara kerja yang lebih tepat dan efisien melalui kelompok arisan PKK. Hasil penelitian yang dilakukan dapat dilihat pada grafik di bawah ini.

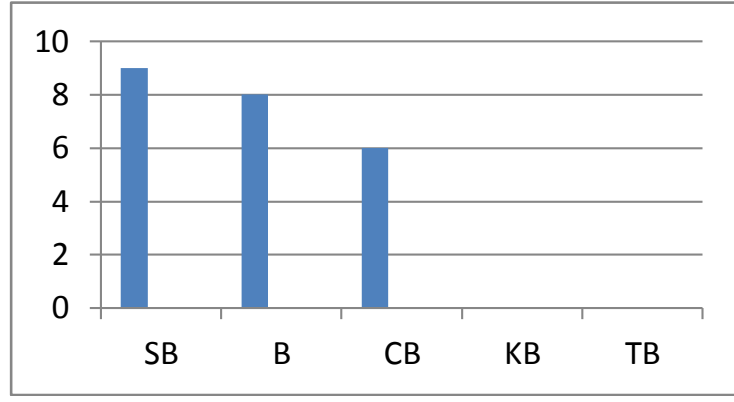

Gambar 3:

Keinginan Belajar

Dari gambar di atas menunjukkan bahwa responden sebanyak 9 orang dari 23 orang memberikan jawaban sangat baik yang berarti bahwa sebagai ibu rumah tangga yang bergabung dalam kelompok arisan PKK memiliki keinginan yang tinggi untuk mempelajari kegiatan. Hal ini ditunjukkan dengan aktifnya ibu rumah tangga dalam mengikuti acara yang diselenggarakan oleh kelompok PKK seperti selalu hadir pada setiap kegiatan arisan dan juga selalu mengikuti berbagai kegiatan keterampilan dan motivasi baik yang berasal dari dalam kelompok itu sendiri maupun yang berasal dari luar kelompok, seperti dari ustad dan ustazah penceramah dan juga dari kelompok perguruan tinggi yang melaksanakan pengabdian.

\section{Kewirausahaan Perempuan Dilihat dari indikator Kemampuan berkomunikasi}

Kemampuan berkomunikasi bermaksud perempuan memiliki kemauan dan kemampuan yang tinggi dalam berkomunikasi di kelompok arisan PKK. Hasil penelitian yang dilakukan dapat dilihat pada grafik dibawah ini.

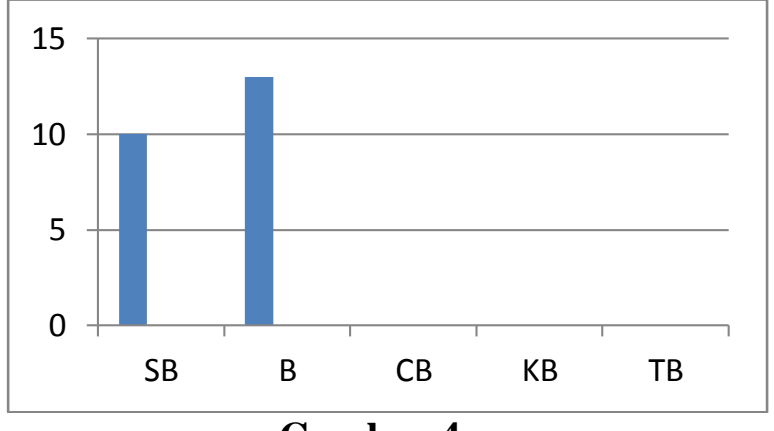

Gambar 4:

Kemampuan Berkomunikasi 
Dari gambar tersebut menunjukkan bahwa responden sebanyak 13 orang dari 23 orang memberikan jawaban baik yang berarti bahwa sebagai ibu rumah tangga yang bergabung dalam kelompok arisan PKK memiliki kemampuan berkomunikasi yang baik. Hal ini ditunjukkan dengan aktifnya ibu rumah tangga dalam mengikuti acara yang diselenggarakan oleh kelompok PKK seperti selalu hadir pada setiap kegiatan arisan dan juga selalu mengikuti berbagai kegiatan keterampilan dan juga motivasi, baik yang berasal dari dalam kelompok itu sendiri maupun yang berasal dari luar kelompok, seperti dari ustad dan ustazah penceramahdan juga dari kelompok perguruan tinggi yang melaksanakan pengabdian.

Kewirausahaan Perempuan Dilihat dari indikator Tantangan Hidup dalam Menghadapi Kondisi Ekonomi Keluarga

Tantangan Hidup dalam menghadapi kondisi keluarga bermaksud perempuan menghadapi hidup dan menangani usaha dengan rencana, jujur, hemat dan disiplin melalui kelompok arisan PKK. Hasil penelitian yang dilakukan dapat dilihat pada grafik dibawah ini.

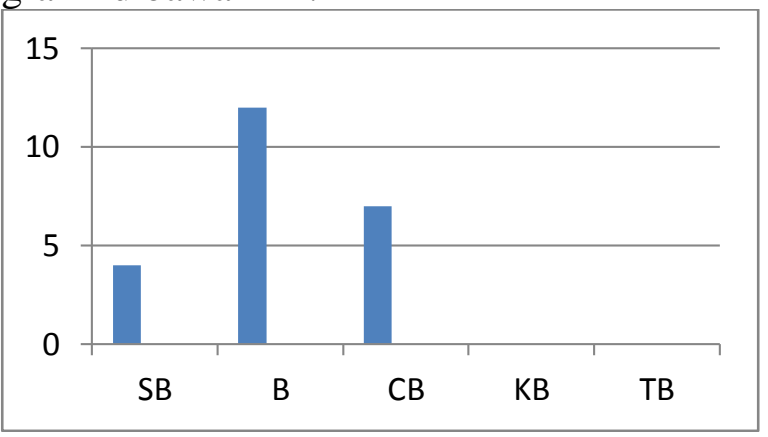

Gambar 5:

\section{Kondisi Ekonomi Keluarga}

Dari gambar tersebut menunjukkan bahwa responden sebanyak 12 orang dari 23 orang memberikan jawaban baik yang berarti bahwa sebagai ibu rumah tangga yang bergabung dalam kelompok arisan PKK memiliki tantangan yang baik. Hal ini ditunjukkan dengan aktifnya ibu rumah tangga dalam mengikuti acara yang diselenggarakan oleh kelompok PKK seperti selalu hadir pada setiap kegiatan arisan dan juga selalu mengikuti berbagai kegiatan keterampilan dan juga motivasi, baik yang berasal dari dalam kelompok itu sendiri maupun yang berasal dari luar kelompok, seperti dari ustad dan ustazah penceramahdan juga dari kelompok perguruan tinggi yang melaksanakan pengabdian.

\section{Kewirausahaan Perempuan Dilihat dari indikator ide kreatif}

Ide kreatif bermaksud perempuan mencari kegiatan usaha serta lugas dan tangguh tetapi cukup luwes melalui kelompok arisan PKK. Hasil penelitian yang dilakukan dapat dilihat pada grafik dibawah ini.

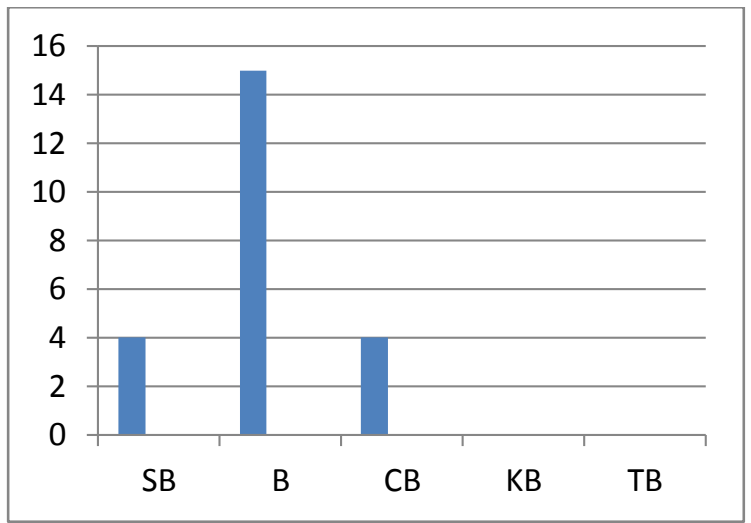

\section{Gambar 6: \\ Ide Kreatif}

Dari gambar tersebut menunjukkan bahwa responden sebanyak 16 orang dari 23 orang memberikan jawaban baik yang berarti bahwa sebagai ibu rumah tangga yang bergabung dalam kelompok arisan PKK memiliki ide kreatif yang baik. Hal ini ditunjukkan dengan aktifnya ibu rumah tangga dalam mengikuti acara yang diselenggarakan oleh kelompok PKK seperti selalu hadir pada setiap kegiatan arisan dan juga selalu mengikuti berbagai kegiatan keterampilan dan juga motivasi baik yang berasal dari dalam kelompok itu sendiri maupun yang berasal dari luar kelompok, seperti dari ustad dan ustazah penceramahdan juga dari kelompok perguruan tinggi yang melaksanakan pengabdian. 


\section{Kewirausahaan Perempuan Dilihat dari Indikator Keinginan Menambah Pengetahuan}

Keinginan menambah pengetahuan bermaksud, perempuan perempuan mencari kegiatan usaha serta lugas dan tangguh tetapi cukup luwes melalui kelompok arisan PKK. Hasil penelitian yang dilakukan dapat dilihat pada grafik di bawah ini.

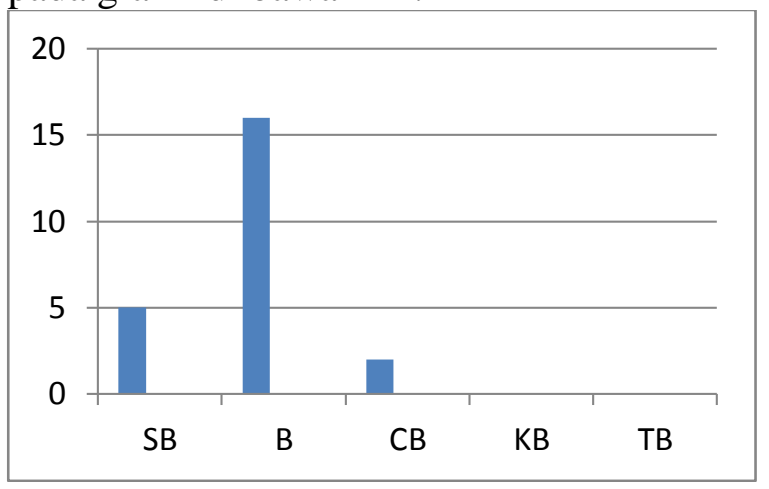

Gambar 7:

Keinginan Menambah Pengetahuan

Dari gambar tersebut menunjukkan bahwa responden sebanyak 16 orang dari 23 orang memberikan jawaban baik yang berarti bahwa sebagai ibu rumah tangga yang bergabung dalam kelompok arisan PKK memiliki rasa percaya diri yang baik. Hal ini ditunjukkan dengan aktifnya ibu rumah tangga dalam mengikuti acara yang diselenggarakan oleh kelompok PKK seperti selalu hadir pada setiap kegiatan arisan dan juga selalu mengikuti berbagai kegiatan keterampilan dan juga motivasi baik yang berasal dari dalam kelompok itu sendiri maupun yang berasal dari luar kelompok, seperti dari ustad dan ustazah penceramahdan juga dari kelompok perguruan tinggi yang melaksanakan pengabdian.

\section{Kewirausahaan Perempuan Dilihat dari Indikator Aktualisasi Diri}

Aktualisasi diri bermaksud perempuan mau dan mampu meningkatkan kapasitas diri sendiri melalui kelompok arisan PKK. Hasil penelitian yang dilakukan dapat dilihat pada grafik dibawah ini.

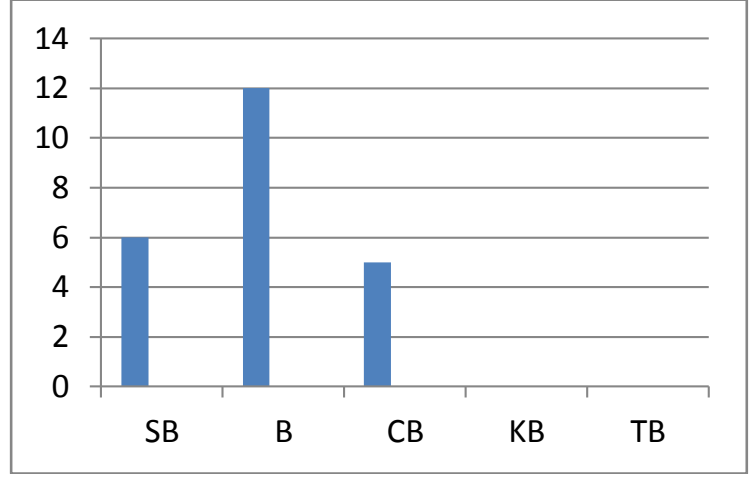

Gambar 8:

Aktualisasi Diri

Dari gambar tersebut menunjukkan bahwa responden sebanyak 12 orang dari 23 orang memberikan jawaban baik yang berarti bahwa sebagai ibu rumah tangga yang bergabung dalam kelompok arisan PKK memiliki aktualisasi diri yang baik. Hal ini ditunjukkan dengan aktifnya ibu rumah tangga dalam mengikuti acara yang diselenggarakan oleh kelompok PKK seperti selalu hadir pada setiap kegiatan arisan dan juga selalu mengikuti berbagai kegiatan keterampilan dan juga motivasi baik yang berasal dari dalam kelompok itu sendiri maupun yang berasal dari luar kelompok, seperti dari ustad dan ustazah penceramahdan juga dari kelompok perguruan tinggi yang melaksanakan pengabdian.

\section{SIMPULAN}

Simpulan yang dapat ditarik adalah jiwa kewirausahaan ibu-ibu rumah tangga pada kelompok PKK adalah berada pada kategori baik terutama kemampuan berkomunikasi berada pada kategori sangat baik $(4,43)$, namun masih lebih rendah dalam hal tantangan ibu rumah tangga menghadapi kondisi ekonomi keluaraga walaupun masih berada pada kategori baik. Faktor yang menghambat kewirausahaan ibu rumah tangga dalam meningkatkan pendapatan rumah tangga diantaranya adalah pendidikan, kondisi ekonomi dan pengalaman 


\section{DAFTAR RUJUKAN}

E. Hadiyati, "Kreativitas dan Inovasi Berpengaruh Terhadap Kewirausahaan Usaha Kecil," J. Manaj. dan kewirausahaan, vol. 13, no. 1, pp. 8-16, 2010.

E. Aprilianty, "Pengaruh Kepribadian Wirausaha, Pengetahuan Kewirausahaan, Dan Lingkungan Terhadap Minat Berwirausaha Siswa SMK," J. Pendidik. Vokas, vol. 2, no. 3, pp. 311-324, 2012.
I. G. P. Darya, "pengaruh ketidakpastian lingkungan dan Karakteristik kewirausahaan terhadap kompetensi usaha dan kinerja usaha mikro kecil di kota balikpapanbalikpapan," Inov. dan Kewirausahaan, vol. 1, no. 1, pp. 65-78, 2012.

Alma Buchari, Kewirausahaan untuk Mahasiswa dan Umum.Penerbit: Alfabeta. Bandung. 2008.

Sunarya, PO Abas, Sudaryono dan Asep Saefullah, 2011, Kewirausahaan, Penerbit ANDI, Yogyakarta. . 